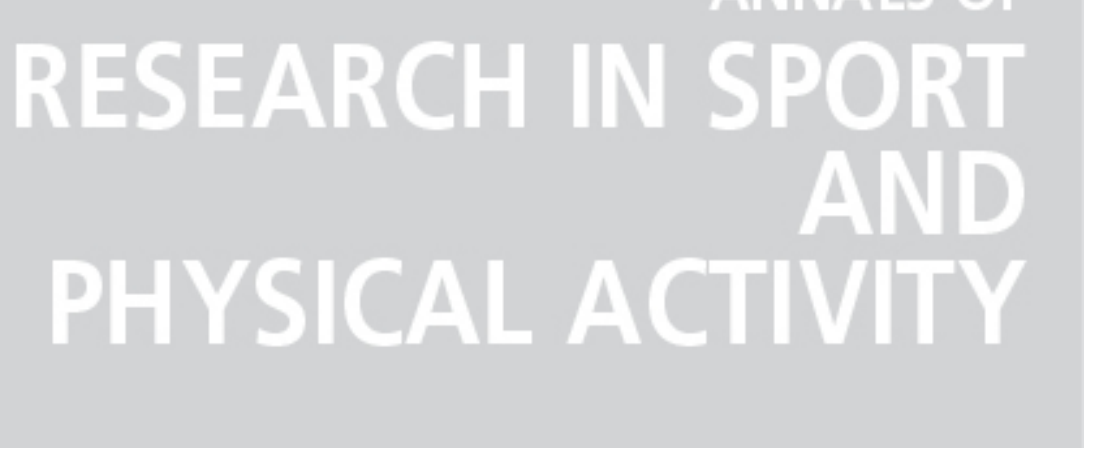

\title{
Scytokine response to exercise and its modulations
}

\author{
Autor(es): $\quad$ Suzuki, Katsuhiko
}

Publicado por: Imprensa da Universidade de Coimbra

URL

persistente:

URI:http://hdl.handle.net/10316.2/44064

DOI:

DOI:https://doi.org/10.14195/2182-7087_ex2018_1

Accessed : $\quad$ 26-Apr-2023 13:30:34

A navegação consulta e descarregamento dos títulos inseridos nas Bibliotecas Digitais UC Digitalis, UC Pombalina e UC Impactum, pressupõem a aceitação plena e sem reservas dos Termos e Condições de Uso destas Bibliotecas Digitais, disponíveis em https://digitalis.uc.pt/pt-pt/termos.

Conforme exposto nos referidos Termos e Condições de Uso, o descarregamento de títulos de acesso restrito requer uma licença válida de autorização devendo o utilizador aceder ao(s) documento(s) a partir de um endereço de IP da instituição detentora da supramencionada licença.

Ao utilizador é apenas permitido o descarregamento para uso pessoal, pelo que o emprego do(s) título(s) descarregado(s) para outro fim, designadamente comercial, carece de autorização do respetivo autor ou editor da obra.

Na medida em que todas as obras da UC Digitalis se encontram protegidas pelo Código do Direito de Autor e Direitos Conexos e demais legislação aplicável, toda a cópia, parcial ou total, deste documento, nos casos em que é legalmente admitida, deverá conter ou fazer-se acompanhar por este aviso. 


\section{ANNALS OF RESEARCH IN SPORT AND PHYSICAL ACTIVITY}




\title{
CYTOKINE RESPONSE TO EXERCISE AND ITS MODULATIONS
}

\author{
Katsuhiko Suzuki ${ }^{1}$
}

KEY WORDS: systemic inflammation, heat stress, energy and fluid supply.

Exhaustive endurance exercise has been shown consistently to induce leukocytosis due to neutrophilia (systemic inflammation), muscle and organ damage and immune suppres$\operatorname{sion}^{(1-5)}$. To determine the underlying mechanisms of these phenomena, much attention has been focused on cytokines released into the circulation following exercise, and indeed there has been a tremendous accumulation of research findings. Many studies have consistently shown that IL-6, IL-8, IL-1 receptor antagonist (IL-1ra) and IL-10 increased remarkably following endurance exercise longer than $2 \mathrm{~h}$, such as marathon and triathlon ${ }^{(2-5,10,15,18,20)}$, but the response of these cytokines is not so significant during short-duration intensive exercise and eccentric exercise ${ }^{(7,9,14,19,32)}$. These responses are not dependent on exercise-induced muscle damage (inflammation), but are related to exercise intensity (physiological load/stress) $)^{(6-8)}$. Indeed, it has been demonstrated that IL-6 response to exercise depends on energy crisis and heat stress, and are correlated with stress hormone responses, but are suppressed by increased energy supply and prior body-cooling interventions ${ }^{(12,13,16,21,22)}$. IL-6 also enhances recruitment of energy substrates, such as free fatty acids, which contributes to endurance performance ${ }^{(5,26)}$. At the same time, IL-6 induces neutrophil mobilization and activation together with immunosuppressive cytokine release of IL-1ra and IL-10 ${ }^{(1-3)}$. Therefore, IL-6 might be good for athletes in optimizing fuel utilization for endurance performance on one hand, but may compromise the immune status of the athlete on the other hand in terms of systemic inflammation and increased susceptibility to infections. It is possible that appropriate countermeasures such as exercising in cool environments, and ensuring sufficient energy and fluid supply together with some functional food might help to maintain endurance performance without causing the harmful side effects on health ${ }^{(11,17}$, $20-23,28)$. These countermeasures may lead to the introduction of new research findings.

\footnotetext{
1 Faculty of Sport Sciences, Waseda University, Tokorozawa, Japan
} 


\section{REFERENCES}

1. Suzuki K, et al. (1999), "Endurance exercise causes interaction among stress hormones, cytokines, neutrophil dynamics, and muscle damage", J. Appl. Physiol, Vol. 87, pp. 1360-1367.

2. Suzuki K, et al. (2000), "Circulating cytokines and hormones with immunosuppressive but neutrophilpriming potentials rise after endurance exercise in humans", Eur. J. Appl. Physiol, Vol. 81, pp. 281-287.

3. Suzuki K, et al. (2003), "Impact of a competitive marathon race on systemic cytokine and neutrophil responses" Med. Sci. Sports Exerc, Vol. 35, pp. 348-355.

4. Suzuki K, et al. (2003), "Exhaustive exercise and type-1/type-2 cytokine balance in special focus on interleukin-12 p40/p70", Exerc. Immunol. Rev, Vol. 9, pp. 48-57.

5. Peake J, et al. (2007), "The influence of antioxidant supplementation on markers of inflammation and the relationship to oxidative stress after exercise", J. Nutr. Biochem, Vol. 18, pp. 357-371.

6. Suzuki K, et al. (2013), "The effects of sports drink osmolality on fluid intake and immunoendocrine responses to cycling in hot conditions" J. Nutr. Sci. Vitamin, Vol. 59, pp. 206-212.

7. Kawanishi N, et al. (2013), "Curcumin attenuates oxidative stress following downhill running-induced muscle damage", Biochem. Biophys. Res. Commun, Vol. 441, pp. 573-578.

8. Sugama K, et al. (2013), "Urinary excretion of cytokines versus their plasma levels after endurance exercise", Exer. Immunol. Rev, Vol. 19. pp 29-48.

9. Suzuki K, et al. (2014), "The effect of a sports drink based on highly branched cyclic dextrin on cytokine responses to exhaustive endurance exercise", J. Sports Med. Phys. Fitness, Vol. 54, pp. 622-630.

10. Suzuki K, et al. (2015), "The acute effects of green tea and carbohydrate coingestion on systemic inflammation and oxidative stress during sprint cycling", Appl. Physiol. Nutr. Metabol, Vol. 40, pp. 997-1003.

11. Kawanishi N, et al. (2016), "Neutrophil depletion attenuates muscle injury after exhaustive exercise", Med. Sci. Sports Exerc, Vol. 48, pp. 1917-1924.

12. Lim CL, et al. (2016), "Systemic inflammation mediates the effects of endotoxemia in the mechanisms of heat stroke", Biol. Med. Vol. 9, pp. 1-4. 